\title{
Desenvolvimento e acúmulo de macronutrientes em plantas de milho biofertilizadas com manipueira
}

\author{
${ }^{1}$ IFPE. Recife, PE. E-mail: coord.pesquisa.extensao@ead.ifpe.edu.br \\ ${ }^{2}$ UFRPE. Recife, PE. E-mail: agmguedes@gmail.com \\ ${ }^{3}$ UFRPE. Recife, PE. E-mail: rolim@dtr.ufrpe.br (Autor correspondente) \\ ${ }^{4}$ UFRPE. Recife, PE. E-mail: elvira.pedrosa@dtr.ufrpe.br \\ ${ }^{5}$ UFRPE. Recife, PE. E-mail: asousaduarte@gmail.com \\ ${ }^{6}$ UFRPE. Recife, PE. E-mail: uetavares@yahoo.com.br
}

Marcela T. L. Barreto ${ }^{1}$, Adriana G. Magalhães ${ }^{2}$, Mario M. Rolim³,

Elvira M. R. Pedrosa ${ }^{4}$, Anamaria de S. Duarte ${ }^{5}$ \& Uilka E. Tavares ${ }^{6}$

\section{Palavras-chave:}

Manihot esculenta

Zea mays

água residuária

mandioca

\begin{abstract}
R E S U M O
Objetivou-se, neste estudo, avaliar o desenvolvimento vegetativo e o acúmulo de macronutrientes em plantas de milho submetidas às doses de manipueira. O experimento foi conduzido em ambiente protegido no período de março a maio de 2011. O delineamento experimental foi inteiramente casualizado em esquema fatorial 2 (tipos de solo: franco-arenoso e franco-argiloso) $\times 4$ (doses de manipueira: 0; 11,2; 22,4 e 44,8 $\mathrm{m}^{3} \mathrm{ha}^{-1}$ ), com oito repetições. As variáveis analisadas foram: altura das plantas, diâmetro de colmos, número de folhas, matéria fresca e matéria seca da parte aérea das plantas e teores de N, P, K, Ca e Mg no tecido foliar. O aumento das doses de manipueira elevou o conteúdo de massa fresca, o teor de nitrogênio e potássio da parte aérea das plantas, mas diminuiu a altura das plantas e o teor de magnésio na parte aérea das plantas. Os acréscimos de matéria seca e de cálcio na parte aérea das plantas foram maiores no solo franco-arenoso.
\end{abstract}

Key words:

Manihot esculenta

Zea mays

wastewater

cassava

\section{Growth and accumulation of macronutrients in maize plants biofertilized with cassava wastewater}

\begin{abstract}
A B S T R A C T
The aim of this study was to evaluate the growth and nutrient accumulation in maize plants fertilized with cassava wastewater. The experiment was carried out under greenhouse from March to May 2011. The experimental design was completely randomized, in a factorial 2 (soil types: sandy loam and clay loam) $\times 4$ (doses of cassava wastewater: $0 ; 11.2 ; 22.4$ and $44.8 \mathrm{~m}^{3} \mathrm{ha}^{-1}$ ) arrangement, with eight replications. The variables analysed consisted of: plant height, stem diameter, number of leaves, fresh and dry mass of shoot and N, P, K, Ca and Mg content in leaf tissue. The use of cassava wastewater contributed to reduce plant height and increase both fresh mass of shoots and potassium content in leaf tissue. Increase in shoot fresh was higher in sandy loam soil.
\end{abstract}

\section{INTRODUÇÃ̃o}

Do beneficiamento das raízes de mandioca para fabricação de farinha de mesa e fécula, são gerados dois tipos de resíduos: a) sólidos, compostos pelas partes lenhosas das raízes, pelas porções fibrosas retidas em peneiras e pelos bagaços da mandioca; e b) líquidos, constituídos da água de lavagem das raízes e da água de prensagem da mandioca, comumente denominada manipueira (Inoue et al., 2011).

A manipueira é um líquido leitoso, amarelo-claro, rico em substâncias orgânicas e nutrientes minerais. Dos subprodutos gerados no processo de industrialização da mandioca, a manipueira é o mais problemático visto que possui elevada concentração de matéria orgânica e linamarina, que é um glicosídeo cianogênico tóxico, do qual provém o ácido cianídrico $(\mathrm{HCN})$, que pode causar sérios problemas ao meio ambiente quando descartado inadequadamente (Vieites, 1998; Barana \& Cereda, 2000).

Segundo Wosiacki \& Cereda (2002), a disposição indiscriminada de manipueira, conhecida pelo poder poluidor e elevada toxidez, traz graves danos ambientais uma vez que, quando descartada em corpos hídricos reduz a disponibilidade de oxigênio dissolvido no meio culminando na morte dos organismos aeróbios; além disto, o lançamento da manipueira no solo prejudica o equilíbrio entre os nutrientes, aumenta a salinidade e diminui o $\mathrm{pH}$ do solo.

Inúmeros nutrientes, no entanto, fazem parte da composição de resíduos agroindustriais justificando o uso desses subprodutos como insumo já que, comprovadamente, o reúso de resíduos para fins agrícolas reduz o uso da água e de fertilizantes, promovendo economia de recursos naturais e melhoria da qualidade do meio ambiente (Laufenberg, 2003). 
É neste contexto que a manipueira se enquadra, haja vista ser a potencialidade de seu uso como adubo decorrente da alta concentração de potássio, nitrogênio, fósforo, cálcio, magnésio e enxofre, além de ferro e outros micronutrientes que este resíduo apresenta (Cardoso et al. 2009; Marini \& Marinho, 2011).

Avaliando a resposta da alface cultivar Verônica à aplicação de doses de manipueira, Santos et al. (2010) verificaram que a manipueira serviu como fonte de adubação e propiciou incremento do número de folhas, do índice de área foliar e, consequentemente, da produção de matéria fresca e seca da parte aérea e raízes das plantas. Resposta semelhante foi encontrada por Saraiva et al. (2007) e Ribas et al. (2010) que, analisando o desenvolvimento vegetativo do milho biofertilizado com manipueira tratada, constataram que o uso de tal efluente ocasionou maior altura de plantas e aumento de macronutrientes no tecido foliar, nas raízes das plantas e no solo, respectivamente.

Por outro lado e apesar de acharem correlações positivas entre as variáveis de crescimento da alface cultivar Regina com o aumento das doses de manipueira, Duarte et al. (2012) relataram que o crescimento e a produção das plantas foram suprimidos com a utilização de doses de manipueira superiores a $45 \mathrm{~m}^{3} \mathrm{ha}^{-1}$. Em consonância com os autores já citados, Schwengber et al. (2010) observaram que o desenvolvimento dos nódulos e o crescimento do feijão caupi diminuíram com o uso de manipueira e as plantas que receberam adubação mineral se desenvolveram melhor que as fertilizadas com tal resíduo.

Com base na hipótese de que o uso indiscriminado de manipueira pode degradar o meio ambiente e que o uso racional deste resíduo é passível de servir como fonte alternativa de adubação para diversas culturas, inclusive o milho, o objetivo desta pesquisa foi investigar o crescimento e o acúmulo de nutrientes por plantas de milho cultivadas em dois solos com texturas distintas e submetidas às doses crescentes de manipueira.

\section{MATERIAl E MÉtodos}

O experimento foi conduzido no período de março a maio de 2011, em uma casa de vegetação pertencente ao Departamento de Tecnologia Rural da Universidade Federal Rural de Pernambuco, Recife, $\mathrm{PE}$, cujas coordenadas geográficas são: $8^{\circ} 1^{\prime}$ ' 1" de latitude Sul e 34 56' 47" de longitude Oeste. O clima, de acordo com a classificação de Koppen, é Megatérmico Tropical (tropical úmido), com temperatura média do mês mais frio superior a $18^{\circ} \mathrm{C}$.

A casa de vegetação media 7,0 $\mathrm{m}$ de largura, $24,0 \mathrm{~m}$ de comprimento, $3,0 \mathrm{~m}$ de pé direito e $4,5 \mathrm{~m}$ de altura com cobertura em arco. As laterais tinham revestimento de tela tipo sombrite $50 \%$ e possuíam rodapé de $20 \mathrm{~cm}$ em alvenaria. A cobertura do ambiente era em filme agrícola de polietileno com $150 \mu \mathrm{m}$ de espessura e tratamento anti-ultravioleta. $O$ piso era revestido com manta geotêxtil na cor cinza $\left(\right.$ bidim $\left.^{\circ}\right)$, com o objetivo de melhorar as condições fitossanitárias e minimizar os efeitos da poeira sobre a casa de vegetação.

Foram coletados, na profundidade de $0 \mathrm{a} 10 \mathrm{~cm}$, dois solos provenientes de Vitória de Santo Antonio, PE, cujas texturas foram classificadas como franco-arenosa e franco-argilosa. Visando à caracterização física e química dos solos, foram retiradas três amostras compostas de cada tipo de solo, as quais foram secadas ao ar, destorroadas e peneiradas em malha de 2 $\mathrm{mm}$, para posterior determinação das características físicas e químicas dos solos antes da incorporação de manipueira (Tabela 1), conforme metodologia proposta pela EMBRAPA (1997).

Tabela 1. Características físicas e químicas do solo utilizado antes do cultivo

\begin{tabular}{lcc}
\hline Parâmetros & \multicolumn{2}{c}{ Teor } \\
\cline { 2 - 3 } Areia $\left(\mathrm{g} \mathrm{kg}^{-1}\right)$ & Solo 1 & Solo 2 \\
Silte $\left(\mathrm{g} \mathrm{kg}^{-1}\right)$ & 698,5 & 642,3 \\
Argila $\left(\mathrm{g} \mathrm{kg}^{-1}\right)$ & 170,5 & 75,7 \\
$\mathrm{CEes}\left(\mathrm{dS} \mathrm{m}^{-1}\right)$ & 131,0 & 282,0 \\
$\mathrm{pH} \mathrm{em} \mathrm{água}$ & 0,84 & 0,26 \\
$\left.\mathrm{~K}\left(\mathrm{cmol}_{\mathrm{c} \mathrm{dm}}\right)^{-3}\right)$ & 5,66 & 5,26 \\
$\mathrm{Ca}\left(\mathrm{cmol}_{\mathrm{c}} \mathrm{dm}^{-3}\right)$ & 0,30 & 0,35 \\
$\mathrm{Mg}\left(\mathrm{cmol}_{\mathrm{c}} \mathrm{dm}^{-3}\right)$ & 2,65 & 2,30 \\
$\mathrm{Na}\left(\mathrm{cmol}_{\mathrm{c}} \mathrm{dm}^{-3}\right)$ & 0,18 & 0,26 \\
$\mathrm{P}\left(\mathrm{mg} \mathrm{kg}^{-1}\right)$ & 0,15 & 0,11 \\
& 17,3 & 9,85 \\
\hline
\end{tabular}

A irrigação foi feita levando-se em consideração a capacidade de campo e, para tanto, foram realizados testes de pesagem dos vasos os quais foram preenchidos da seguinte forma: $500 \mathrm{~g}$ de brita número 0 , para permitir a drenagem da água; manta (bidim ${ }^{\circ}$, para evitar a perda do solo e $10 \mathrm{~kg}$ do solo utilizado para o cultivo; após a montagem três vasos foram saturados por capilaridade e pesados diariamente até se obter peso constante, ou seja, quando o solo se encontrava em capacidade de campo.

A partir desses testes foi obtido o peso médio dos três vasos com solo em capacidade de campo e, como todos os vasos utilizados para o plantio no experimento foram preenchidos da mesma forma, o volume de água necessário para cada planta foi obtido pela diferença do peso médio dos três vasos com o solo em capacidade de campo e o peso de cada um desses vasos contendo uma planta, os quais eram pesados diariamente.

A cultura teste utilizada nesta pesquisa foi o milho (Zea mays L.) forrageiro híbrido AG 1051 da Agroceres, que foi desenvolvido para a produção de milho verde e silagem tendo, como características, ciclo semiprecoce, em média 115 dias para ensilagem e 144 dias para colheita de grãos; alta produção de grãos e de matéria fresca. Neste experimento a semeadura do milho foi realizada no vigésimo primeiro dia após a aplicação da manipueira no solo, tempo necessário para estabilização de seus nutrientes e eliminação do ácido cianídrico. Em cada vaso foi disposta apenas uma semente a cerca de um centímetro de profundidade, cujo cultivo durou 42 dias, período em que as plantas apresentavam seis pares de folhas completamente expandidas e antecede a emissão do pendão, segundo Fancelli (1986).

O delineamento experimental foi inteiramente casualisado em esquema fatorial $2 \times 4$; com oito repetições totalizando 64 parcelas experimentais. Os fatores de estudo da pesquisa foram: solos (2 tipos), sendo um com textura franco-arenosa e outro com textura franco-argilosa e doses de manipueira (quatro), equivalentes a $0 ; 11,2 ; 22,4 \mathrm{e} 44,8 \mathrm{~m}^{3} \mathrm{ha}^{-1}$. As doses de 
manipueira foram determinadas levando-se em consideração a concentração de potássio existente no resíduo e no solo, tal como a exigência desse nutriente pela cultura do milho, que é $20 \mathrm{~kg}$ $\mathrm{ha}^{-1}$, de acordo com a recomendação proposta por IPA (2008). Não foi conveniente a realização de calagem nem tampouco foi realizada adubação mineral durante o experimento, com o objetivo de verificar apenas o efeito que o uso da manipueira exerceu sobre a cultura.

A manipueira utilizada foi oriunda de uma casa de farinha localizada no município de Pombos, PE. A determinação da composição física e química da manipueira (Tabela 2) foi realizada no Laboratório de Engenharia Ambiental e da Qualidade (LEAQ) e no Laboratório de Mecânica dos Solos e Aproveitamento de Efluentes da UFPE e UFRPE, respectivamente. Os parâmetros físicos e químicos foram determinados de acordo com a metodologia proposta por APHA (1995).

Tabela 2. Características físicas e químicas da manipueira

\begin{tabular}{lcc}
\hline \multicolumn{1}{c}{ Parâmetros } & Unidade & Teor \\
Sólidos totais & $\mathrm{mg} \mathrm{L}^{-1}$ & $65.773,5$ \\
Sólidos totais voláteis & $\mathrm{mg} \mathrm{L}^{-1}$ & $47.327,0$ \\
Sólidos totais fixos & $\mathrm{mg} \mathrm{L}^{-1}$ & $18.446,5$ \\
DQ0 & $\mathrm{mg} \mathrm{L}^{-1}$ & $82.871,1$ \\
DB0 & $\mathrm{mg} \mathrm{L}^{-1}$ & $44.624,2$ \\
Condutividade elétrica & $\mathrm{dS} \mathrm{m}^{-1}$ & 7,81 \\
pH & & 5,83 \\
Potássio & $\mathrm{mg} \mathrm{L}^{-1}$ & $5.900,0$ \\
Nitrogênio & $\mathrm{mg} \mathrm{L}^{-1}$ & $1.592,3$ \\
Fósforo & $\mathrm{mg} \mathrm{L}^{-1}$ & 667,5 \\
Magnésio & $\mathrm{mg} \mathrm{L}^{-1}$ & $1.532,3$ \\
Cálcio & $\mathrm{mg} \mathrm{L}^{-1}$ & 376,0 \\
Sódio & $\mathrm{mg} \mathrm{L}^{-1}$ & 126,0 \\
\hline
\end{tabular}

Para acompanhar o desenvolvimento das plantas foram monitorados os seguintes parâmetros: altura de plantas (AP), diâmetro de colmo (DC) e número de folhas (NF), com frequência semanal; massa verde (MFPA) e massa seca (MSPA) da parte aérea das plantas, por ocasião do final do experimento, conforme metodologia proposta por Benincasa (2003). Foram determinados, também, os teores de $\mathrm{N}, \mathrm{P}, \mathrm{K}^{+}, \mathrm{Ca}^{2+}, \mathrm{Mg}^{2+}$ e $\mathrm{Na}^{+}$ no tecido vegetal foliar, segundo a metodologia descrita por Bezerra Neto \& Barreto (2011).

Os dados obtidos foram submetidos à análise de variância utilizando-se o software estatístico SISVAR, com nível de significância de 0,05 para o teste de média e regressão dos dados.

\section{Resultados e Discussão}

Não houve interação entre doses e solos $(\mathrm{p}>0,05)$ para as variáveis de crescimento, exceto massa seca da parte aérea (Tabela 3). O diâmetro do caule não foi afetado por nenhum fator isoladamente ou em conjunto; entretanto, a altura das plantas respondeu significativamente $(\mathrm{p}<0,05)$ ao fator isolado dose, o número de folhas ao fator isolado solo e a massa fresca da parte aérea aos fatores dose e solo, isoladamente (Tabela 3).
Tabela 3. Resumo da ANOVA para altura de planta (AP), diâmetro de colmo (DC), número de folhas (NF), matéria fresca (MFPA) e matéria seca (MSPA) da parte aérea das plantas

\begin{tabular}{|c|c|c|c|c|c|c|}
\hline \multirow{2}{*}{$\begin{array}{l}\text { Fontes de } \\
\text { variação }\end{array}$} & \multirow{2}{*}{ GL } & \multicolumn{5}{|c|}{ Quadrado médio } \\
\hline & & $\overline{A P}$ & DC & NF & MFPA & MSPA \\
\hline Doses & 3 & $451,2^{\star \star}$ & $0,063^{\text {ns }}$ & $0,124167^{\text {ns }}$ & $5089,060^{*}$ & $16,84^{\text {ns }}$ \\
\hline Solos & 1 & $3,37^{\text {ns }}$ & $0,001^{\text {ns }}$ & $1,562500^{\star}$ & $17556,25^{\star \star}$ & $42,90^{\text {ns }}$ \\
\hline Doses x Solos & 3 & $75,8^{\text {ns }}$ & $0,053^{\text {ns }}$ & $0,384167^{\text {ns }}$ & $1443,75^{\mathrm{ns}}$ & $47,53^{*}$ \\
\hline Resíduo & 56 & 86,1 & 0,029 & 0,226607 & 940,29 & $13,51^{\text {ns }}$ \\
\hline CV (\%) & & 10,7 & 11,4 & 5,76 & 12,95 & 16,26 \\
\hline
\end{tabular}

nsNão significativo a nível de 0,05 de probabilidade;

${ }^{*} \mathrm{e}$ ** Significativos a 0,05 e 0,01 de probabilidade, respectivamente, pelo teste $F$ CV - Coeficiente de variação

O aumento das doses de manipueira ocasionou um decréscimo significativo na altura das plantas de milho (Figura $1 \mathrm{~A})$, sendo que na ausência de manipueira a altura média das plantas foi igual a $92,3 \mathrm{~cm}$ e quando foi aplicada a maior dose do efluente $\left(44,8 \mathrm{~m}^{3} \mathrm{ha}^{-1}\right)$, o valor médio da altura das plantas foi de $79,8 \mathrm{~cm}$ decaindo aproximadamente $14 \%$. Schwengber et al. (2010) também constataram que a altura das plantas de feijão caupi diminuiu quando se utilizou manipueira como fonte de adubação e as plantas que receberam adubação
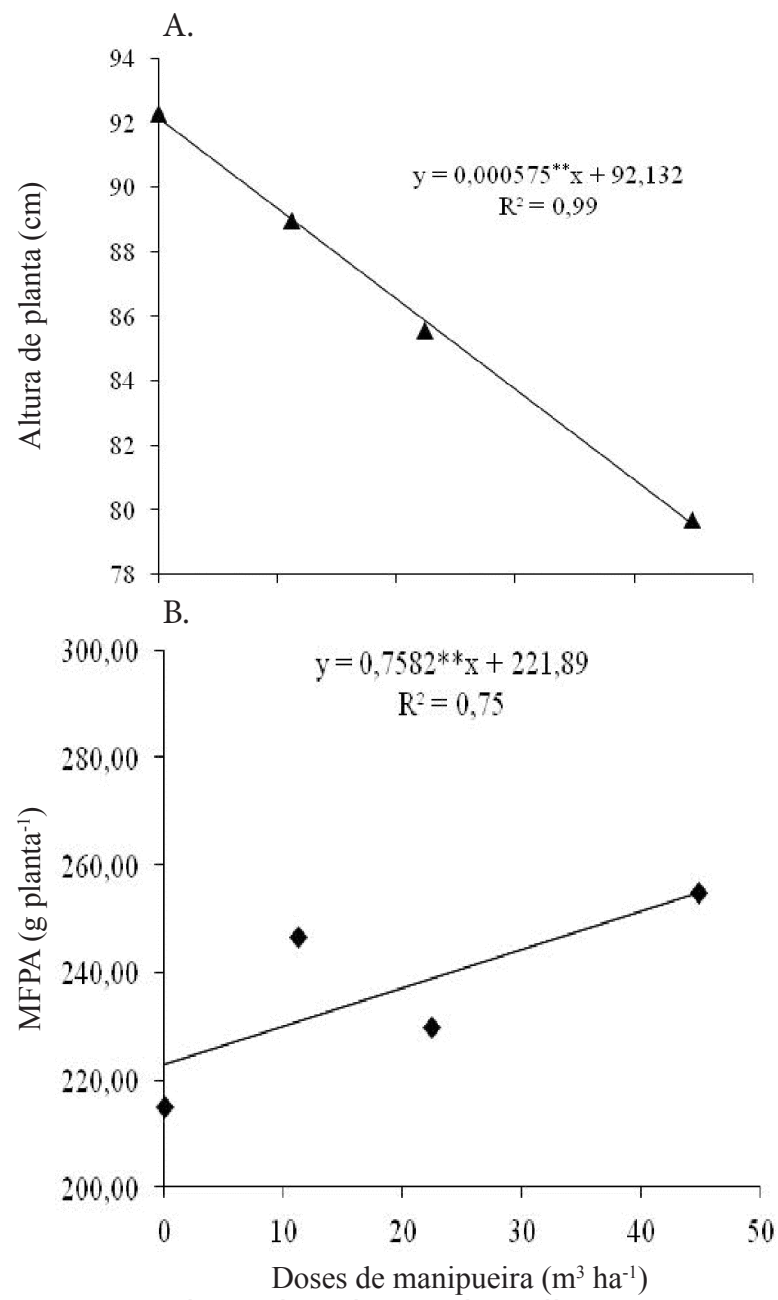

Figura 1. Altura das plantas de milho (A) e massa fresca da parte aérea (MFPA) das plantas de milho (B) em função de doses de manipueira 
mineral se desenvolveram melhor que as fertilizadas com tal resíduo.

É provável que as respostas encontradas para as variáveis altura de planta e diâmetro de colmo estejam relacionadas aos elementos existentes em excesso na manipueira os quais podem, quando adicionados ao solo, provocar restrições no crescimento, no conteúdo da matéria fresca e seca da parte aérea e radicular das plantas e ainda alterar seus estádios vegetativos e reprodutivos (Bovi et al., 2002). Segundo Fageria (2001), as interações entre nutrientes são mensuradas através da resposta de crescimento da cultura e de mudanças nos teores de nutrientes na planta; apesar disto, as interações entre os nutrientes podem ser sinérgicas ou antagônicas dependendo da resposta de crescimento das plantas.

Para as variáveis altura de planta e diâmetro de colmo os resultados aqui obtidos discordam daqueles apresentados por Saraiva et al. (2007) quando constataram que o uso de manipueira tratada como fonte de adubação na cultura do milho aumentou a altura e o diâmetro do colmo das plantas em um período experimental de oitenta dias; esses autores ressaltaram, também, que as plantas que receberam maiores dosagens do resíduo concentrado apresentaram maiores diâmetros de colmo que as que receberam adubação mineral e o resíduo diluído. Em outro estudo, Ribas et al. (2010) também relataram que a altura e o diâmetro do colmo das plantas de milho não foram afetados negativamente pela adubação com manipueira tratada e estabilizadas com agentes alcalinos.

Ressalta-se que a manipueira utilizada nos dois trabalhos citados anteriormente foi tratada antes de sua utilização ocorrendo, com isto, redução dos nutrientes presentes na manipueira, sobretudo, $\mathrm{K}, \mathrm{Ca}, \mathrm{Mg}, \mathrm{Na}, \mathrm{Fe}$ e $\mathrm{Zn}$ os quais, quando em excesso, podem ser prejudiciais às plantas; assim, a divergência entre os resultados encontrados pelos referidos autores e os resultados obtidos nesta pesquisa parece estar associada ao fato da manipueira utilizada ser proveniente de fecularia que, antes da utilização, foi tratada contribuindo para a diminuição da concentração da carga orgânica, de macro e micronutrientes encontrados no resíduo, conforme relatam Barana \& Cereda (2000).

Diminuição de altura de plantas foi verificada por Duarte et al. (2012), quando aplicaram manipueira "in natura" no solo cultivado com alface e constataram que doses acima de 45 $\mathrm{m}^{3} \mathrm{ha}^{-1}$ de manipueira suprimiram o crescimento das plantas evidenciando, neste caso, o efeito prejudicial da manipueira às plantas de alface, se utilizadas doses superiores a $45 \mathrm{~m}^{3} \mathrm{ha}^{-1}$.

O número médio de folhas das plantas cultivadas no solo franco-arenoso foi significativamente maior que o número de folhas das plantas cultivadas no solo franco-argiloso, sendo encontrados valores iguais a 8,42 e 8,11, no solo franco-arenoso e no solo franco-argiloso, respectivamente. Trabalhando com adubação mineral Andreotti et al. (2001), também observaram que o número de folhas do milho submetido às doses crescentes de adubação potássica e às diferentes saturações por bases foi maior no solo arenoso que no solo argiloso. Segundo os autores, este fato foi ocasionado devido, possivelmente, à maior disponibilidade de nutrientes na solução do solo arenoso, nos períodos iniciais de crescimento da cultura.

Com relação à matéria fresca da parte aérea das plantas (Figura $1 \mathrm{~B}$ ), ocorreu maior acúmulo nas plantas cultivadas no solo franco-argiloso sendo que o maior conteúdo foi de 260,6 g planta $^{-1}$ quando se utilizou a dose equivalente a $44,8 \mathrm{~m}^{3} \mathrm{ha}^{-1}$ de manipueira; já no solo franco-arenoso o menor acúmulo de matéria fresca se deu na ausência de manipueira (197,5 g planta $\left.^{-1}\right)$ e o maior acúmulo $\left(249,4\right.$ g planta $\left.^{-1}\right)$ foi obtido quando se utilizou a maior dose de manipueira, sugerindo que os nutrientes presentes na manipueira foram bem aproveitados pelas plantas.

O fato das plantas cultivadas em solo franco-argiloso apresentarem maior conteúdo de matéria fresca da parte aérea do que as plantas cultivadas no solo franco-arenoso, parece estar relacionado com a retenção de nutrientes (P, K, $\mathrm{Ca}$ e $\mathrm{Mg}$ ) pela fração de argila uma vez que o teor de argila afeta a disponibilidade e a mobilidade dos nutrientes, bem como o teor de água no solo, fatores esses que favorecem a redução de difusão dos nutrientes entre o solo e as raízes das plantas (Sangoi et al., 2009). Os resultados obtidos corroboram as observações realizadas por Mélo et al. (2006) quando estudaram o deslocamento de cátions advindos da adição de manipueira em três tipos de solo (Neossolo Quartzarênico órtico espódico, Latossolo Amarelo distrófico típico e Latossolo Vermelho Amarelo distrófico típico) do Estado de Minas Gerais.

Os resultados obtidos neste estudo também são semelhantes aos encontrados por Cardoso et al. (2009) ao constatarem que as plantas de milho cultivadas em área adubada com manipueira tratada apresentaram maior produção de matéria fresca da parte aérea que as plantas cultivadas em solo adubado com fertilizante mineral, sendo o aumento creditado aos nutrientes presentes na manipueira sobretudo potássio e nitrogênio. Incremento na produção de matéria fresca em hortícolas em função do uso de manipueira como fonte de adubação também foi relatado em trabalhos realizados por Santos et al. (2010) e Duarte et al. (2012).

Embora a matéria seca da parte aérea das plantas não tenha sido afetada significativamente pelos fatores doses e solos isoladamente, a interação desses dois fatores foi significativa ( $\mathrm{p}$ $<0,05)$ (Tabela 3). Pelo desdobramento da interação verificou-se que a utilização de doses crescentes de manipueira provocou aumento linear positivo da matéria seca das plantas cultivadas no solo franco-arenoso, porém favoreceu, em contrapartida, um decréscimo desta variável nas plantas cultivadas no solo franco-argiloso (Figura 2).

Os dados de matéria seca da parte aérea das plantas (Figura 2) revelaram que o maior conteúdo de matéria seca foi encontrado para as plantas cultivadas em solo franco-arenoso e que receberam maior dose de manipueira; por outro lado, o menor acúmulo de matéria seca ocorreu nas plantas cultivadas no solo franco-argiloso adubado com a maior dose do resíduo. A massa seca da parte aérea das plantas cultivadas no solo franco-arenoso foi igual a $21,0 \mathrm{~g}_{\text {plantas }}{ }^{-1}$ quando não se utilizou 


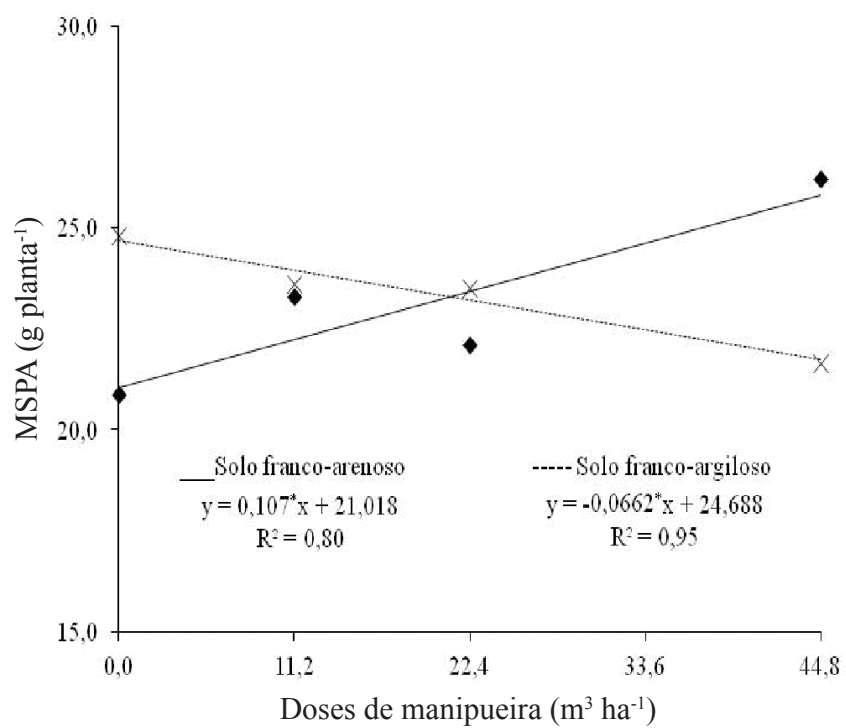

Figura 2. Massa seca da parte aérea das plantas de milho em função de doses de manipueira e tipos de solo

manipueira aumentando para 25,8 $\mathrm{g}$ plantas $^{-1}$ quando se utilizou a maior dose de tal resíduo $\left(44,8 \mathrm{~m}^{3} \mathrm{ha}^{-1}\right)$. Já as plantas cultivadas no solo franco-argiloso apresentaram maior conteúdo de massa seca na ausência de manipueira $\left(24,7\right.$ g plantas $\left.^{-1}\right)$, sendo o menor valor encontrado quando se aplicou a maior dose do resíduo $\left(21,7\right.$ g plantas $\left.^{-1}\right)$.

As respostas relativas à matéria seca da parte aérea das plantas obtidas se assemelham às encontradas por Oliveira et al. (2009), quando cultivaram mamona, variedades BRS Nordestina e BRS Paraguaçu, em dois tipos de solo (Latossolo e Neossolo) adubados com biossólidos. Os autores relataram que as plantas cultivadas no Neossolo apresentaram maior massa seca da parte aérea do que as plantas cultivadas no Latossolo; fato ocorrido porque, possivelmente, as plantas cultivadas no solo com maior percentagem de areia, no caso o Neossolo, se beneficiam dos nutrientes que se encontram prontamente disponíveis na solução do solo facilitando sua absorção pelas plantas.

Embora não tenha ocorrido interação entre solo e doses de manipueira para os elementos N, P e K no tecido foliar das plantas, o comportamento desses elementos foi distinto: o $\mathrm{N}$ foi afetado significativamente $(\mathrm{p}<0,05)$ pelo tipo de solo, mas não pelas doses do resíduo; $\mathrm{O} P$ não foi afetado por nenhum dos fatores e o K foi afetado $(\mathrm{p}<0,05)$ por ambos fatores (Tabela 4$)$. Por outro lado, os elementos $\mathrm{Ca}$ e $\mathrm{Mg}$ se mostraram sensíveis à interação solo e dose de manipueira, tal como aos efeitos isolados desses fatores.
Para N, as plantas cultivadas no solo franco-argiloso apresentaram maior teor que as cultivadas no solo francoarenoso; entretanto e independentemente do tipo de solo, o teor médio de $\mathrm{N}$ no tecido foliar das plantas aumentou com o aumento da dose do resíduo (Figura $3 \mathrm{~A}$ ). Este fato está relacionado, provavelmente, à maior fração de argila existente no solo franco-argiloso que, por ter maior riqueza natural de $\mathrm{N}$ disponível para as plantas, garantiu maiores quantidades deste elemento o qual foi prontamente aproveitado pelas plantas, conforme Ernani et al. (2005). Por outro lado e de acordo com IPA (2008), apenas as plantas cultivadas no solo franco-argiloso e que receberam a maior dose de manipueira apresentaram

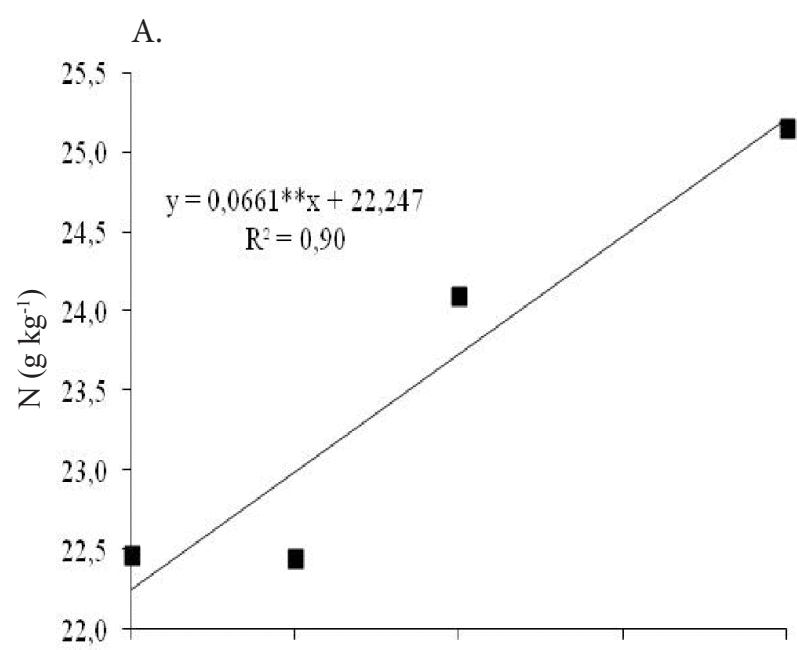

B.

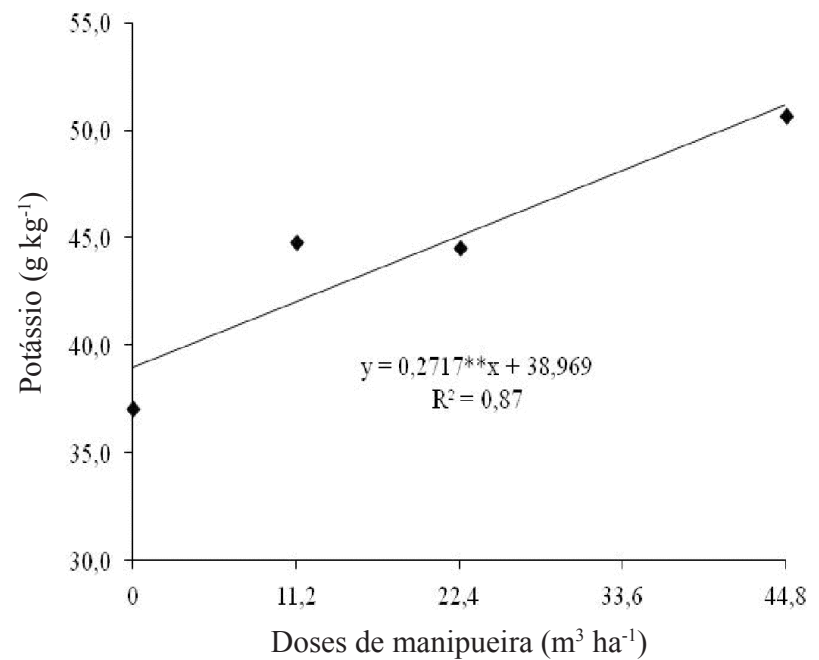

Figura 3. Teor de nitrogênio (A) e de potássio (B) no tecido foliar das plantas de milho em função de doses de manipueira

Tabela 4. Resumo da ANOVA para os teores de N, $\mathrm{P}$ e K+, $\mathrm{Ca}^{2+}$ e $\mathrm{Mg}^{2+}$ no tecido foliar das plantas de milho sob diferentes doses de manipueira em dois solos

\begin{tabular}{|c|c|c|c|c|c|c|}
\hline \multirow{2}{*}{$\begin{array}{c}\text { Fontes de } \\
\text { variaçãa }\end{array}$} & \multirow{2}{*}{ GL } & \multicolumn{5}{|c|}{ Quadrado médio } \\
\hline & & $\mathbf{N}$ & $\mathbf{P}$ & K & $\mathrm{Ca}$ & $\mathrm{Mg}$ \\
\hline Solos & 1 & $345,727539^{* *}$ & $1,772227^{\mathrm{ns}}$ & $541,900202^{\star *}$ & $22,1153^{\star \star}$ & $56,1587^{\star \star}$ \\
\hline CV (\%) & & 16,59 & 24,28 & 17,29 & 16,80 & 17,01 \\
\hline
\end{tabular}

ns Não significativo até 0,$05 ;{ }^{*} \mathrm{e}$ ** Significativos a 0,05 e 0,01 de probabilidade, respectivamente, pelo teste $\mathrm{F}$

CV - Coeficiente de variação 
teor de $\mathrm{N}$ considerado adequado para a cultura do milho (27,5 a $\left.32,5 \mathrm{~g} \mathrm{~kg}^{-1}\right)$.

$\mathrm{O}$ fato do teor de $\mathrm{P}$ no tecido foliar não ser afetado por nenhum dos fatores pode estar associado à imobilização deste elemento no solo, contribuindo para a menor absorção do nutriente pelas plantas (Malavolta, 1997). Entretanto, independente do tipo de solo usado no presente estudo as plantas mostraram teores médios de $\mathrm{P}$ adequados no tecido foliar $\left(2,64 ; 3,0 ; 2,92\right.$ e $3,56 \mathrm{~g} \mathrm{~kg}^{-1}$ quando se utilizaram doses equivalentes a $0 ; 11,2 ; 22,4 \mathrm{e} 44,8 \mathrm{~m}^{3} \mathrm{ha}^{-1}$ ), tomando-se como base IPA (2008) que considera adequados para a cultura do milho valores entre 2,5 e $3,5 \mathrm{~g} \mathrm{~kg}^{-1}$ de $\mathrm{P}$.

Quanto ao acúmulo de $\mathrm{K}$ na planta verifica-se efeito significativo dos fatores doses e solos isoladamente (Tabela 4), com maior acúmulo nas plantas cultivadas em solo francoargiloso. Independentemente do tipo de solo, o acúmulo de K na parte aérea das plantas aumentou com os incrementos das doses (Figura $3 \mathrm{~B}$ ), evidenciando que o K presente na manipueira foi intensamente absorvido pelas plantas.

Os resultados permitem inferir que o potássio proveniente da manipueira incorporada ao solo foi intensamente absorvido pelas plantas concordando com a afirmação de Primo et al. (2012), quando assinalam que o nitrogênio e o potássio são os elementos mais exigidos pela cultura do milho e, por isso, são extraídos em maior quantidade pelas plantas.

Segundo IPA (2008), o teor de potássio no tecido foliar de plantas de milho deve estar entre 17,5 e 22,5 $\mathrm{g} \mathrm{kg}^{-1}$; sendo assim verifica-se, a partir dos dados obtidos, que o teor de potássio encontrado nas plantas cultivadas foi superior aos considerados adequados para a cultura do milho.

Os resultados obtidos divergem das respostas encontradas por Saraiva et al. (2007) e por Inoue et al. (2011), quando constataram que o potássio advindo da manipueira tratada não foi suficiente para manter níveis adequados de potássio no tecido foliar das plantas pois parte do elemento contido na manipueira é perdida quando se trata o resíduo, além de que este nutriente se encontrava presente em concentrações bem mais baixas do que na manipueira utilizada neste trabalho (Tabela 2).

Com relação à interação entre solo e dose de manipueira para os elementos Ca e Mg (Tabela 4), constatou-se efeito quadrático (Figura 4A) no teor de Ca das plantas em função do aumento das doses de manipueira nos dois tipos de solo. Para Mg, a utilização de doses crescentes de manipueira provocou decréscimo linear no teor deste elemento na planta, nos dois solos utilizados. As respostas encontradas neste estudo concordam com as obtidas por Ribas et al. (2010), quando relatam que a aplicação de manipueira como fonte de adubação do milho também provocou inibição da absorção de cálcio e magnésio pelas plantas, durante a fase inicial de desenvolvimento.

Nas plantas cultivadas em solo franco-arenoso, o teor médio de Ca no tecido foliar variou de 1,07 a $1,70 \mathrm{~g} \mathrm{~kg}^{-1}$, na ausência e na presença da maior dose de manipueira, respectivamente enquanto nas plantas cultivadas em solo franco-argiloso, quando não se incorporou manipueira ao solo, o teor médio de Ca foliar foi de $0,87 \mathrm{~g} \mathrm{~kg}^{-1}$, elevando-se para $1,37 \mathrm{~g} \mathrm{~kg}^{-1}$
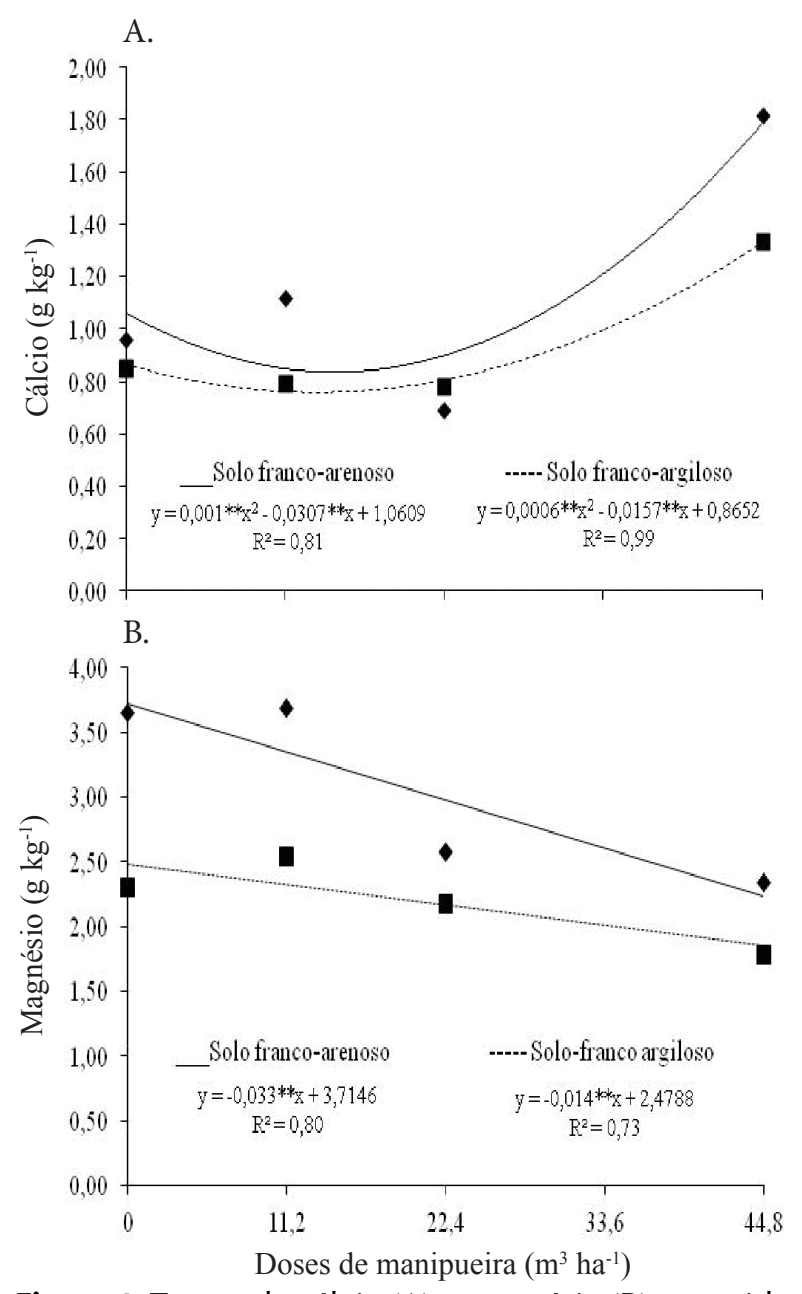

Figura 4. Teores de cálcio (A) e magnésio (B) no tecido foliar das plantas de milho em função de doses de manipueira e tipos de solo

quando se utilizou a maior dose do resíduo. Em relação ao Mg, quando se utilizou a maior dose de manipueira os teores médios deste elemento nas plantas cultivadas em solo franco-arenoso e em solo franco-argiloso, foram iguais a 3,71 e $2,48 \mathrm{~g} \mathrm{~kg}^{-1}$, respectivamente, decrescendo linearmente para valores iguais a 2,2 e $1,85 \mathrm{~g} \mathrm{~kg}^{-1}$ nas plantas cultivadas, respesctivamente, em solo franco-arenoso e franco-argiloso.

De acordo com IPA (2008), os teores de Ca e Mg considerados adequados para a cultura do milho, variam de 2,5 a $4,0 \mathrm{~g} \mathrm{~kg}^{-1}$ evidenciando que o aumento das doses de manipueira prejudicou a absorção de $\mathrm{Mg}$ pelas plantas; este fato ocorreu devido, possivelmente, à alta concentração de $\mathrm{K}$ existente na manipueira (Tabela 2), já que Fageria (2001) menciona haver antagonismo entre esses elementos de modo que a absorção de um deles pode ser diminuída em virtude da presença excessiva do outro, no caso, $\mathrm{K}$.

Simonete et al. (2003) relataram, avaliando o efeito de biossólidos no crescimento e na nutrição de milho, que as quantidades de $\mathrm{Ca}$ e Mg acumuladas pelas plantas aumentaram com a aplicação das doses de lodo de esgoto; no entanto, a complementação com adubação potássica diminuiu a absorção de Ca e Mg pelas plantas. 
Incrementos na produção em função do uso de manipueira como fonte de adubação foram relatados em vários estudos (Vieites, 1998; Santos et al., 2010; Duarte et al., 2012). Entretanto, Vieites (1998) observou que, embora o uso de manipueira como alternativa à adubação foliar tenha contribuído para aumentar o rendimento dos frutos comercializáveis do tomateiro, só foi eficiente após a complementação com adubação mineral. Por outro lado, Marini \& Marinho (2011) concluíram que a aplicação de manipueira não afetou a produção de mexerica (Citrus deliciosa Tenore).

Apesar da utilização de resíduos orgânicos como fonte de adubação para diferentes culturas ser uma alternativa viável e trazer bons rendimentos, dificilmente são obtidas produções iguais ou superiores às produções obtidas com a adubação mineral (Gomes et al. 2005). Entretanto, diversos trabalhos apontam que a junção da adubação orgânica com a adubação mineral pode maximizar a produtividade agrícola e reduzir custos com fertilizantes, além de melhorar a qualidade ambiental.

Comparando o efeito de diferentes doses de adubo orgânico (esterco) e adubação mineral na cultura do milho, Huang et al. (2010) concluíram que, em curto prazo, a adubação mineral garantiu boa produção porém em períodos consecutivos de cultivo não foi capaz de garantir melhoras no rendimento da cultura; entretanto, quando a adubação mineral foi utilizada em conjunto com a adubação orgânica a produtividade das plantas foi superior em todos os períodos do cultivo. Resposta semelhante foi obtida por Cavallaro Júnior et al. (2009), quando utilizaram diferentes resíduos associados à adubação mineral no cultivo do tomate e da rúcula.

\section{Conclusões}

1. A manipueira pode ser utilizada como alternativa de adubação para a cultura do milho sendo necessária a utilização de doses adequadas a fim de se evitar o efeito deletério de alguns nutrientes contidos neste resíduo, principalmente o potássio.

2. A utilização de doses crescentes de manipueira propiciou um acúmulo de massa fresca, nitrogênio e potássio na parte aérea das plantas, independente do tipo de solo cultivado; no entanto, a altura das plantas e o teor de magnésio encontrado na parte aérea das plantas diminuíram em função do aumento das doses do referido resíduo.

3. As plantas cultivadas no solo franco-arenoso apresentaram maior incremento de massa seca e maior teor de cálcio na parte aérea do que as plantas cultivadas no solo franco-argiloso com a elevação das doses de manipueira.

\section{Agradecimentos}

Os autores agradecem à Sociedade Nordestina de Ecologia (SNE) e ao Serviço de Tecnologia Alternativa (SERTA) pela concessão da manipueira utilizada no experimento e à Coordenação de Aperfeiçoamento de Pessoal de Nível Superior (CAPES) pelo auxílio financeiro.

\section{Literatura Citada}

Andreotti, A.; Rodrigues, J. D.; Crusciol, C. A. C.; de Souza, E. C. A.; Bull, L.T. Crescimento do milho em função da saturação por bases e da adubação potássica. Scientia Agricola, v.58, p.145-150, 2001.

APHA - American Public Health Association, AWWA - American Water Works Association, WPCF - Washington Press Club Foundation. Standard methods for the examination of water and wastewater. Washington: American Public Health Association, 17.ed. 1995. 2198p.

Barana, A. C; Cereda, M. P. Cassava wastewater (manipueira) treatment using a two-phase anaerobic biodigestor. Ciência e Tecnologia de Alimentos, v.20, p.183-186, 2000.

Benincasa, M. M. P. Análise de crescimento de plantas: Noções básicas. 2.ed. Jaboticabal: FUNEP, 2003. 41p.

Bezerra Neto, E.; Barreto, L. P. Análises químicas e bioquímicas em plantas. Recife: UFRPE, 2011.267p.

Bovi, M. L. A.; Godoy Júnior, G.; Spiering, S. H. Respostas de crescimento da pupunheira à adubação NPK. Scientia Agrícola, v.59, p.161-166, 2002.

Cardoso, E.; Cardoso, D.; Cristiano, M.; Silva, L.; Back, A. J.; Bernadim, A. M.; Paula, M. M. S. Use of manihot esculenta, crantz processing residue as biofertilizer in corn crops. Research Journal of Agronomy, v.3, p.1-8, 2009.

Cavallaro Júnior, Trani, P. E.; Passos, F. A; Kunh neto, J.; Tivelli, S. W. Produtividade de rúcula e tomate em função da adubação N e P orgânica e Mineral. Bragantia, v.68, p.347-356, 2009.

Duarte, A. S.; Silva, E. F. F.; Rolim, M. M.; Ferreira, R. F. A. L.; Malheiros, S. M. M.; Albuquerque, F. S. Uso de diferentes doses de manipueira na cultura da alface em substituição à adubação mineral. Revista Brasileira de Engenharia Agrícola e Ambiental, v.16, p.262-267, 2012.

EMBRAPA - Empresa Brasileira de Pesquisa Agropecuária. Manual de análises químicas de solos, plantas e fertilizantes. Brasília: EMBRAPA, 1997. 370p.

Ernani, P. R.; Sangoi, L.; Lech, V. A.; Rampazzo, C. A forma de aplicação da uréia e dos resíduos vegetais afeta a disponibilidade de nitrogênio. Ciência Rural, v.35, p.360365, 2005.

Fageria, N. K. Nutrient interactions in crop plants. Journal of Plant Nutrition, v.24, p.1269-1290, 2001.

Fancelli, A. L. Plantas alimentícias: Guia para aula, estudos e discussão. Piracicaba: ESALQ, 1986. 131p. Dissertação Mestrado

Gomes, J. A., Scapim, C. A., Braccini, A. L.; Filho, P. S.V.; Sagrilo, E.; Moura, F. Adubação orgânica e mineral, produtividade de milho e características físicas e químicas de um Argissolo vermelho amarelo. Acta Scientiarum Agronony, v.27, p. 521-529, 2005.

Huang, S.; Zhang, W.; Yu, X.; Huang, Q. Effects of long-term fertilization on corn productivity and its sustainability in an Ultisol of southern China. Agriculture Ecosystem Environment, v.138, p.44-50, 2010. 
Inoue, K. R. A.; Souza, C. F; Matos, A. T.; Santos, N. T.; Ferreira, W. P. M. Concentração de nutrientes em plantas de milho adubadas e biofertilizantes obtidos na digestão anaeróbia da manipueira. Engenharia na Agricultura, v.19, p.236-243, 2011.

IPA - Instituto Agronômico de Pernambuco. Recomendações de adubação para o Estado de Pernambuco. Recife: IPA, 2008. 64p.

Laufenberg, G. Transformation of vegetable waste into added products: (A) the upgrading concept; (B) practical implementations. Bioresource Technology, v.87, p.167-198, 2003.

Malavolta, E. Avaliação do estado nutricional das plantas: Princípios e aplicações. 2.ed. Piracicaba: POTAFOS, 1997. 319 p.

Marini, F. S.; Marinho, C. S. Adubação complementar para a mexeriqueira 'Rio' em sistema de cultivo orgânico Revista Brasileira de Engenharia Agrícola e Ambiental, v.15, p.562568, 2011.

Mélo, R. F.; Ferreira, P. A.; Ruiz, H. A.; Matos, A. T.; Oliveira, L. B. O. Deslocamento miscível de cátions básicos provenientes da água residuária de mandioca em colunas de solo. Revista Brasileira de Engenharia Agrícola e Ambiental, v.10, p.456465, 2006.

Oliveira, J. P. B.; Lopes, J. C.; Alexandre, R. S.; Jasper, A. P.; Santos, L. N. S. Efeito do lodo de esgoto no desenvolvimento inicial de duas cultivares de mamona em dois tipos de solos. Engenharia Ambiental, v.5, p.203-219, 2009.

Primo, D. C.; Menezes, R. S. C.; da Silva, T. O.; Garrido, M. S.; Cabral, P. K. T. Contribuição da adubação orgânica na absorção de nutrientes e na produtividade de milho no semiárido paraibano. Revista Brasileira de Ciências Agrárias, v.7, p.81-88, 2012.
Ribas, M. M. F.; Cereda, M.P.; Villas-Boas, R.L. Use of cassava wastewater treated anaerobically with alkaline agents as fertilizer for maize (Zea mays L.). Brazilian Archives of Biology and Technology, v.53, p.55-62, 2010.

Sangoi, L.; Ernani, P. R.; Bianchet, P.; Vargas, V. P.; Picolli, G. J. Efeito de doses de cloreto de potássio sobre a germinação e o crescimento inicial do milho, em solos com texturas contrastantes. Revista Brasileira de Milho e Sorgo, v.8, p.187-197, 2009.

Santos, M. H. V.; Araújo, A C. de.; Santos, D. M. R.; Lima, N. S.; Lima, A. C. A.; Lima, C. L. C.; Santiago, A. D. Uso da manipueira como fonte de potássio na cultura da alface (Lactuca sativa, L.) cultivada em casa-de-vegetação. Acta Scientiarum Agronomy, v.32, p.729-733, 2010.

Saraiva, F. Z.; Sampaio, S. C.; Silvestre, M. G.; Queiroz, M. M. F. de; Nóbrega, L. H. P.; Gomes, B. M. Uso de manipueira no desenvolvimento vegetativo do milho em ambiente protegido. Revista Brasileira de Engenharia Agrícola e Ambiental, v.11, p.30-36, 2007.

Schwengber, J. A. M.; Silva, F. F.; Smiderle, O. J.; Schewengber, D. R. Nodulação do feijão-caupi em função da aplicação de três águas de farinheira. Revista em Agronegócios e Meio Ambiente, v.3, p.135-146, 2010.

Simonete, M. A.; Kiehl, J. de C.; Andrade, C. A.; Teixeira, C. F. A. Efeito do lodo de esgoto em um Argissolo e no crescimento e nutrição de milho. Pesquisa Agropecuária Brasileira, Brasília, v.38, p.1187-1195, 2003.

Vieites, R. L. Efeitos da adubação com manipueira sobre o rendimento e qualidade dos frutos de tomate. Pesquisa Agropecuária Brasileira, v.33, p.45-47, 1998.

Wosiacki, G.; Cereda, M. P. Valorização de resíduos de processamento da mandioca. Publicatio UEPG, v.8, p.2743, 2002. 